\title{
Functional significance of a partial-emersion response in the intertidal prawn Palaemon elegans (Crustacea: Palaemonidae) during environmental hypoxia
}

\author{
A. C. Taylor, J. I. Spicer \\ Department of Zoology, University of Glasgow, Glasgow G12 8QQ, Scotland
}

\begin{abstract}
During exposure to severe hypoxia $\left(<20\right.$ Torr $\left.\left[2.7 \times 10^{3} \mathrm{~Pa}\right]\right)$ under both laboratory and field conditions, prawns Palaemon elegans Rathke frequently exhibited a partial-emersion response during which they moved into shallow water and became quiescent, usually lying on their sides at the water's edge. The $P_{\mathrm{O}_{2}}$ at which this behavioural response occurred appeared to be dependent on temperature; at higher temperatures the prawns exhibited this response at higher oxygen tensions. When exposed to anoxic conditions in the laboratory, $P$. elegans sometimes left the water and emerged onto boulders. Investigations of the physiological advantages of the partial-emersion response demonstrated that the total oxygen content of the blood was significantly higher and the concentration of $\mathrm{L}$ lactate lower than that of either fully immersed or totally emersed prawns. It appears, therefore, that $P$. elegans is able to exploit the higher oxygen tensions at the air/water interface and can meet most of its metabolic demands via aerobic metabolism. Although prawns which emerge completely from the water when exposed to anoxia may be able to utilize air as a source of oxygen, they are faced with problems of acid-base disturbance in the blood due to the difficulties of $\mathrm{CO}_{2}$ excretion. In these prawns, the total $\mathrm{CO}_{2}$ content of the blood was significantly higher and the $\mathrm{pH}$ lower than that of partially-emersed prawns. By remaining in contact with the water, partially-emersed prawns gain an important respiratory advantage and are able to reduce the problems both of acid-base disturbance and of desiccation during total emersion.
\end{abstract}

\section{INTRODUCTION}

The prawn Palaemon elegans Rathke is a common inhabitant of intertidal rock pools on European coasts and is regularly exposed to periods of low environmental oxygen tension that are a feature of the rock pool environment (Stephenson et al. 1934, Daniel \& Boyden 1975, Truchot \& Duhamel-Jouve 1980, Morris \& Taylor 1983). The respiratory and metabolic responses of this species to environmental hypoxia have been the subject of several recent studies (Morris \& Taylor 1985, Morris et al. 1985, Taylor \& Spicer 1987 and unpubl., Taylor 1988). P. elegans is well adapted to withstand hypoxia and is able to maintain its rate of oxygen consumption over a wide range of ambient oxygen tension down to a critical tension $\left(P_{\mathrm{c}}\right)$ of less than 20 Torr $\left(2.7 \times 10^{3} \mathrm{~Pa}\right)$ (Morris \& Taylor 1985). Below this critical tension, the normal aerobic respiration rates cannot be sustained and there is a shift from aerobic to anaerobic metabolism which results in the production of lactic acid. Although $P$. elegans is able to tolerate even severe hypoxic stress, it is incapable of surviving more than a few hours exposure to anoxia (Taylor \& Spicer 1987).

During studies of acid-base disturbance in the blood and the metabolic changes accompanying exposure to environmental hypoxia in Palaemon elegans, it was noted that this species exhibited certain behavioural responses which might be of importance in enabling individuals to survive periods of exposure to severe hypoxia in intertidal rock pools. The aim of the present study was to characterize these behavioural adaptations and to assess their importance in minimising physiological disturbance during exposure to environmental hypoxia.

\section{MATERIAL AND METHODS}

Collection and maintenance of specimens. Palaemon elegans were collected from intertidal pools at the HWN level on a rocky promontory to the west of Kames 
Bay, on the Isle of Cumbrae, Firth of Clyde, Scotland. Prawns were collected using a hand-held net at regular intervals thoughout the period February to June, 1987. After collection, the prawns were transported back to the Zoology Department, University of Glasgow, in large plastic containers (40 l) of seawater. Palaemon serratus (Pennant) were obtained from the specimen supply department of the Marine Biological Association at Plymouth, England. Specimens were kept for at least 1 wk at $10^{\circ} \mathrm{C}$ in a seawater aquarium in the laboratory before being used in any experiment. During this time, they were fed regularly on mussels Mytilus edulis (L.) and were subject to a $12 / 12 \mathrm{~h}$ light/ dark regime. They were starved for $2 \mathrm{~d}$ before the start of the experiments.

Behavioural observations. Behavioural observations were carried out on Palaemon elegans at 10 and $20^{\circ} \mathrm{C}$ under the following conditions. A $10 \mathrm{l}$ transparent, plastic tank was filled with $5 \mathrm{l}$ of artificial seawater (Tropic Marine) having a salinity of $30 \%$. A number of small sandstone boulders, collected from rock pools on the Isle of Cumbrae, were placed in the tank and, by being semi-submerged, allowed the prawns to move into more shallow water or even to leave the water completely. Five individuals were placed in the tank and left for 2 to $3 \mathrm{~h}$ to acclimatize to the experimental conditions. After this time, the oxygen tension $\left(P_{\mathrm{O}_{2}}\right)$ of the water was reduced at a constant rate by bubbling a gas mixture produced by gas mixing pumps (Wösthoff, Bochum, FRG) through the water. The $P_{\mathrm{O}_{2}}$ decreased at a rate of approximately 80 Torr $\mathrm{h}^{-1}$ to produce a final $P_{\mathrm{O}_{2}}$ of $<1$ Torr $\left(1.3 \times 10^{2} \mathrm{~Pa}\right)$. The partial pressure of $\mathrm{CO}_{2}$ in the gas mixture $\left(P_{\mathrm{CO}_{2}}\right)$ was held constant at 0.8 Torr. The behavioural responses of the prawns were monitored continuously thoughout the experiment. Some comparative experiments were also carried out under identical conditions on the closely related Palaemon serratus.

Field observations. Recordings of the behaviour of Palaemon elegans in rock pools on the Isle of Cumbrae, Firth of Clyde, were made at different times of the year. Observations were made throughout the day but most recordings took place at night when the $P_{\mathrm{O}_{2}}$ of the water in the rock pools was at its lowest. Further recordings were carried out on 2 occasions at Wembury, near Plymouth, Devon, England, since at this location it was possible to find both $P$. elegans and $P$. serratus in the intertidal pools. This enabled us to make an interesting comparative study of the behaviour of these 2 species.

Hypoxia and anoxia experiments. In the laboratory, measurements were made of the changes in $\mathrm{pH}$, total carbon dioxide content $\left(\mathrm{C}_{\mathrm{CO}_{2}}\right)$ and the concentration of L-lactate in the blood of Palaemon elegans exposed to hypoxic conditions. Attempts were also made to monitor in vivo blood oxygen tensions using a Searle neonatal oxygen probe (1.35 $\mathrm{mm}$ diameter) but, due to the small size of even the largest prawns $(2.72 \mathrm{~g})$, this was unsuccessful. Determinations of the total oxygen content of the blood $\left(\mathrm{C}_{\mathrm{O}_{2}}\right)$ were carried out, however, on $10 \mu 1$ blood samples taken from the pericardium (see below).

Three large plastic tanks (volume $=10 \mathrm{l}$ ) were set up in a temperature-controlled room at $10^{\circ} \mathrm{C}$. Two of the tanks contained 51 of seawater (salinity $=30 \%$ ) made up from artificial sea salts (Tropic Marine) dissolved in deionized water which had been left overnight in the room to equilibrate to the experimental temperature. One tank was covered with a polystyrene sheet $15 \mathrm{~mm}$ thick), which was cut to fit the inside of the tank and which, when floating on the water surface, substantially reduced the air/water interface and helped to prevent the diffusion of oxygen back into the water. An oxygen electrode (E5046, Radiometer, Denmark), coupled to an oxygen meter (Strathkelvin Instruments, Glasgow) and a pen recorder (Smith's Servoscribe), was fitted through a hole in the polystyrene sheet to enable the $P_{\mathrm{O}_{2}}$ to be monitored continuously throughout the experiment. The prawns in this tank were therefore exposed to hypoxic conditions but were unable to move into shallow water where the oxygen tension may have been slightly higher or to exhibit an emersion response (see below). These are referred to subsequently as immersed prawns.

The second tank was not covered and was provided with small boulders which allowed the prawns either to enter shallow water or even to completely leave the water. The $P_{\mathrm{O}_{2}}$ of the water in the tanks was maintained at a constant level by bubbling the required gas mixture, produced by a precision gas mixing system, through 2 air-stones situated at either end of the experimental tanks. A third (empty) tank was lined with filter paper soaked in seawater ( $\mathrm{S}=30 \%$ ). After prawns had been introduced into this tank, it was covered with a moistened paper towel to ensure the maintenance of a high relative humidity. These are referred to subsequently as emersed prawns

Thirty Palaemon elegans (fresh wt range 1.34 to 2.66 g) were introduced into each of the tanks containing seawater and left undisturbed for $12 \mathrm{~h}$. After this time 5 individuals were removed and these were taken as controls (Time 0). The oxygen tension of the water was then reduced by bubbling a predetermined gas mixture having a $P_{\mathrm{O}_{2}}$ of either 10 Torr $(1.3 \times 10 \mathrm{~Pa})$ or 0 Torr through the water. The percentage of $P_{\mathrm{CO}}$ in the gas mixture was adjusted to maintain a constant water pH and $P_{\mathrm{CO}_{2}}$ throughout each of the experiments. The oxygen tension of the water decreased at a rate of approximately 160 Torr $\mathrm{h}^{-1}$, and this rate of depletion was maintained for each of the experiments. A further 
30 individuals were gently removed from their holding tanks, blotted dry and then placed in the tank lined with moistened filter paper. Fifteen individuals were removed for blood sampling (see below) at 3 and $6 \mathrm{~h}$ intervals in the 10 Torr experiment and 20 individuals were removed for blood sampling after exposure to anoxia for $2 \mathrm{~h}$. Control prawns which had been maintained under normoxic conditions throughout the experiments were also sampled at the same time intervals.

Determination of blood $\mathrm{pH}, \mathrm{C}_{\mathrm{O}_{2}}, C_{\mathrm{CO}_{2}}$ and L-lactate concentrations. After removal from the water, the individuals were quickly blotted dry, with special attention being paid to the posterior region of the carapace. Blood samples to be used in lactate analysis were taken from each prawn by inserting a fine gauge hypodermic needle attached to a $1 \mathrm{ml}$ syringe into the pericardium. The blood was then ejected from the syringe into an Eppendorf tube and assayed immediately using the method of Gutman \& Wahlefeld (1974) with the modifications suggested by Graham et al. (1983).

The in vivo $\mathrm{pH}$ of the blood was measured by drawing the blood directly from the pericardium into the capillary $\mathrm{pH}$ electrode of a Radiometer B.M.S. II maintained at $10^{\circ} \mathrm{C}$ and connected to a Corning model 155 $\mathrm{pH}$ meter. The total $\mathrm{CO}_{2}$ content $\left(\mathrm{C}_{\mathrm{CO}_{2}}\right)$ and the total oxygen content $\left(C_{\mathrm{O}_{2}}\right)$ of post-branchial blood were determined in $10 \mu \mathrm{l}$ samples taken anaerobically from the pericardium. The $\mathrm{C}_{\mathrm{CO}_{2}}$ of the blood was determined using the method of Cameron (1971) and the $\mathrm{C}_{\mathrm{O}_{2}}$ of the blood was determined using the method of Tucker (1967) as modified by Bridges et al. (1979). All values quoted are means $\pm \mathrm{SD}$.

\section{RESLLTS}

\section{Behavioural observations}

When exposed to conditions of declining oxygen tension, Palaemon elegans showed an increase in locomotor activity. If presented with the opportunity, most prawns moved quickly into the shallow parts of the tanks and then became quiescent, usually lying on their sides parallel to the water's edge. This behaviour was noted only when the $P_{\mathrm{O}_{2}}$ of the seawater was reduced to less than $25 \operatorname{Torr}\left(3.3 \times 10^{3} \mathrm{~Pa}\right)$ at $10^{\circ} \mathrm{C}$, but at $20^{\circ} \mathrm{C}$ this response was elicited at higher oxygen tensions (ca 40 Torr $\left[5.3 \times 10^{3} \mathrm{~Pa}\right]$ ). Prawns which did not have access to shallow water often swam to the surface of the water at the sides of the tanks where they adopted an inverted position so that the ventral surface of the body was uppermost and was in close proximity to the air/water interface. Having adopted this position, the pleopods continued to beat in short bursts and created a current of water around the body, Although both behaviour patterns were regularly observed in $P$. elegans during exposure to hypoxic conditions, neither were recorded in experiments with the closely related $P$. serratus. When exposed to declining oxygen tensions, $P$. serratus normally remained quiescent at the bottom of the tanks. On entering shallow water, Palaemon elegans normally lay on their sides with their ventral surfaces parallel to the water's edge. After 1 to 5 min, a slow metachronal beating of the pleopods commenced causing water to be circulated around the prawns. The rate of pleopod beating varied considerably (rates of 52 to 99 beats min $^{-1}$ were counted in different individuals). The scaphognathites remained active throughout this period of partial-emersion. In fact there was a marked hyperventilation of the branchial chambers with the resting rate of beating of the scaphognathites (120 to 150 beats $\mathrm{min}^{-1}$ ) increasing to between 250 and 350 beats min $^{-1}$.

In this position the uppermost branchial chamber was partially-emersed so that the scaphognathite beat was concentrated at the air/water interface. Pleopod and scaphognathite beating was the dominant activity during this partial emersion response although occasionally some of the prawns did continue with stereotyped grooming behaviour involving the use of the second pereiopods.

During exposure to hypoxia the prawns would remain in this position at the air/water interface for long periods often until the $P_{\mathrm{O}_{2}}$ of the water in the tanks was increascd by aeration. When exposed to exireme hypoxia or to totally anoxic conditions, Palaemon elegans left the water completely and crawled up the exposed surface of the rocks until fully emersed despite the fact that the pereiopods seem poorly adapted to bear the full weight of the body. More typically, however, the prawns remained partially immersed or close to the water's edge so that desiccation stress was reduced. Occasionally, prawns resting in the shallow region flicked their tails, thus propelling themselves out of the water and on to the boulders. This behaviour was not well coordinated, however, since they sometimes propelled themselves back into the deeper parts of the tanks.

Once fully emersed the prawns remained quiescent, exhibiting occasional tail-flicks which were sometimes sufficient to propel them back into the water. In contrast to the partially-emersed prawns, fully emersed individuals showed a complete cessation of scaphognathite activity. Some preliminary experiments on the ability of Palaemon elegans to survive periods of aerial exposure indicated that this species was normally able to survive in air (relative humidity $=100 \%$ ) for over $12 \mathrm{~h}$. Prawns which exhibited this partial emersion response, however, often re-entered hypoxic or even 
anoxic water when disturbed although they returned to the shallows within a few minutes.

\section{Physiological effects of the emersion response}

The effects of hypoxia-induced emersion on the $\mathrm{C}_{\mathrm{O}_{2}}$, $\mathrm{pH}, \mathrm{C}_{\mathrm{CO}_{2}}$ and L-lactate concentration of the blood of Palaemon elegans are presented in Table 1. The total oxygen content of the blood of immersed prawns showed a significant reduction $(p<0.05)$ during the period of exposure to severe hypoxia (10 Torr). In emersed prawns, the reduction in the $\mathrm{C}_{\mathrm{O}_{2}}$ of the blood was even greater $\left(C_{\mathrm{O}_{2}}=0.15 \pm 0.12 \mathrm{mmol}^{-1}\right)$. In contrast, the blood $\mathrm{C}_{\mathrm{O}_{2}}$ of prawns which exhibited the partial-emersion response did not show a significant reduction $(p>0.05)$ from that of the controls maintained in normoxic water.

Within $3 \mathrm{~h}$ of exposure to severe hypoxia $\left(P_{\mathrm{O}_{2}}=10\right.$ Torr), the $\mathrm{pH}$ of the blood of immersed and partiallyemersed prawns had increased significantly $(p<0.01)$. There was no significant difference between the $\mathrm{pH}$ of the blood of immersed and partially-emersed prawns $(p>0.05)$. The $\mathrm{pH}$ of the blood remained elevated and did not decrease even after $6 \mathrm{~h}$ exposure to severe hypoxia. In contrast, the pH of the blood of emersed prawns declined significantly $(p<0.05)$ to $7.13 \pm 0.05$ after $3 \mathrm{~h}$ and remained at this low value even after $6 \mathrm{~h}$ exposure.

Some recent studies of blood acid-base balance in decapod crustaceans have indicated that in vivo conditions were not in a steady state thus precluding the use of the Henderson-Hasselbalch equation to calculate in vivo $P_{\mathrm{CO}_{2}}$ (DeFur et al. 1980, McMahon et al. 1983, Booth et al. 1984, DeFur \& McMahon 1984). Burton (1987) has also discussed in some detail the problems of using the Henderson-Hasselbalch equation to calculate $\mathrm{HCO}_{3}$ concentrations in vertebrates for which accurate information on the appropriate constants is not available. DeFur \& McMahon (1984) suggest that the inapplicability of the Henderson-Hasselbalch equation makes it impossible to construct accurate 'Davenport' diagrams (Davenport 1974). We have followed DeFur \& McMahon (1984) in presenting data in the form of a plot of $\mathrm{pH}$ versus $\mathrm{C}_{\mathrm{CO}_{2}}$ (Fig. 1) which allows a comparison to be made between the in vivo data and the in vitro system as represented by a common buffer line.

Although there was no significant difference in the total $\mathrm{C}_{\mathrm{CO}_{2}}$ of the blood of immersed and partiallyemersed prawns, when these data are plotted against the $\mathrm{pH}$ of the blood (Fig. 1) a marked metabolic alkalosis is demonstrated. In fully emersed prawns, however, the $\mathrm{C}_{\mathrm{CO}_{2}}$ of the blood increased from a resting level of $2.7 \pm 0.4$ to a value of $8.0 \pm 0.6 \mathrm{mmol} \mathrm{l}^{-1}$ after $6 \mathrm{~h}$ aerial exposure.

In all of the experimental groups there was an increase in the L-lactate concentration of the blood, even after $3 \mathrm{~h}$ (Table 1). This increase was most pronounced in the blood of the immersed prawns in which the concentration of lactate in the blood increased after exposure to hypoxia (10 Torr) for $6 \mathrm{~h}$ and was least in the blood of partially-emersed prawns in which the concentration of lactate after $6 \mathrm{~h}$ hypoxic exposure, although still elevated, was significantly lower $(p<$ $0.01)$ than in either the immersed or the emersed prawns.

After exposure to anoxia for $2 \mathrm{~h}$, the blood $\mathrm{pH}$ of immersed prawns had decreased significantly (Table 2). This acidosis was primarily metabolic in origin for there was very little change in the $\mathrm{C}_{\mathrm{CO}_{2}}$ of the blood whereas the concentration of L-lactate had increased significantly $(p<0.01)$. The immersed prawns were extremely lethargic after this time and survival was not high even after they had been returned to normoxic conditions. In the case of partially-emersed prawns,

Table 1. Palaemon elegans. Total oxygen content $\left(C_{\mathrm{O}_{3}}\right)$, carbon dioxide content $\left(C_{\mathrm{Co}_{2}}\right), \mathrm{pH}$ and L-lactate concentration of the blood of prawns exposed to hypoxic water $(10$ Torr) for 3 and $6 \mathrm{~h}$. Values are for totally inmersed, partially-emersed, and emersed prawns, and for control prawns maintained in normoxic water. Values are means $\pm \mathrm{SD}, n=6$

\begin{tabular}{lcccc|}
\hline & $\begin{array}{c}\mathrm{C}_{\mathrm{O}_{2}} \\
\left(\mathrm{mmol} \mathrm{l}^{-1}\right)\end{array}$ & $\begin{array}{c}\mathrm{C}_{\mathrm{CO}_{2}} \\
\left(\mathrm{mmol} \mathrm{I}^{-1}\right)\end{array}$ & pH & $\begin{array}{c}\text { L-lactate } \\
\left(\mathrm{mmol} \mathrm{I}^{-1}\right)\end{array}$ \\
\hline Hypoxic interval 3 $\mathbf{h}$ & & & & \\
Control & $0.71 \pm 0.24$ & $2.8 \pm 0.3$ & $7.79 \pm 0.03$ & $0.41 \pm 0.22$ \\
Immersed & $0.37 \pm 0.14$ & $3.0 \pm 0.6$ & $7.94 \pm 0.03$ & $3.74 \pm 0.49$ \\
Partially-emersed & $0.63 \pm 0.22$ & $2.5 \pm 0.4$ & $7.98 \pm 0.11$ & $2.98 \pm 0.88$ \\
Emersed & $0.15 \pm 0.12$ & $6.2 \pm 0.6$ & $7.13 \pm 0.05$ & $3.70 \pm 1.82$ \\
Hypoxic interval 6 $\mathbf{h}$ & & & & \\
Control & & $2.7 \pm 0.4$ & $7.78 \pm 0.05$ & $0.46 \pm 0.22$ \\
Immersed & & $3.2 \pm 0.3$ & $7.90 \pm 0.07$ & $6.03 \pm 0.66$ \\
Partially-emersed & & $2.8 \pm 0.3$ & $7.10 \pm 0.07$ & $4.01 \pm 0.95$ \\
Emersed & & $8.0 \pm 0.5$ & $5.60 \pm 0.92$ \\
\hline
\end{tabular}




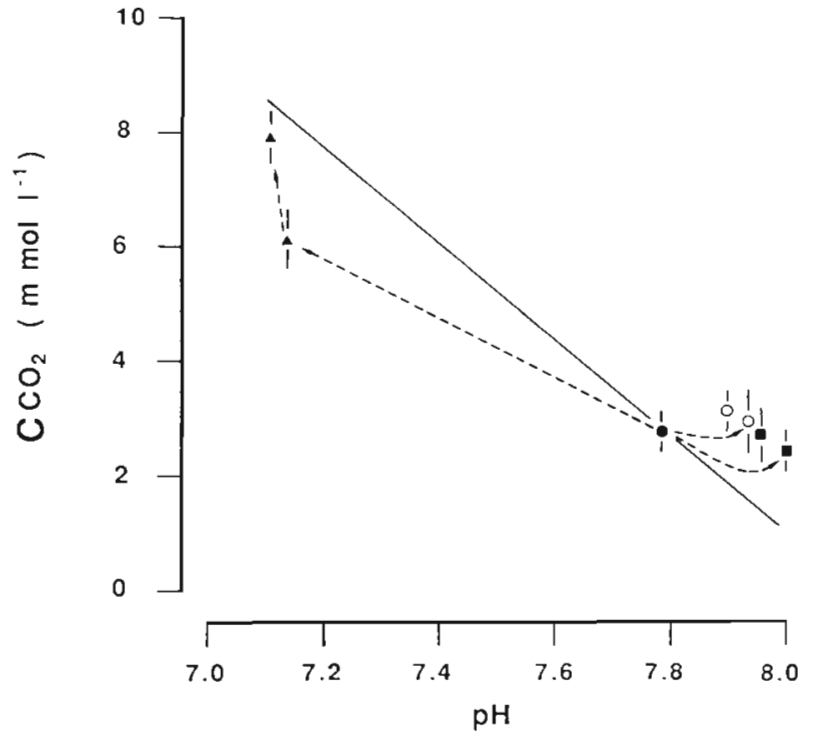

Fig. 1. Palaemon elegans. Relation between total carbon dioxide content $\left(C_{\mathrm{CO}_{0}}\right)$ and $\mathrm{pH}$ of the blood of prawns exposed to hypoxia in the laboratory. Values given are for fully immersed $(0)$, partially-emersed ( $\square$ ) and emersed ( 4 ) prawns after 3 and 6 $\mathrm{h}$ exposure and for control prawns $(\bullet)$ maintained under normoxic conditions. Solid line represents mean buffer line for the oxygenated blood of $P$. elegans at $10^{\circ} \mathrm{C}$. Vertical lines are $\mathrm{SD}$

Table 2. Palaemon elegans. Carbon dioxide content $\left(C_{\mathrm{CO}_{2}}\right), \mathrm{pH}$ and $L$-lactate concentration of the blood of prawns exposed to anoxic water for $2 \mathrm{~h}$. Values are for totally immersed, partiallyemersed and emersed prawns, and for control prawns main-

tained in normoxic water. Values are means $\pm \mathrm{SD}_{1} n=6$

\begin{tabular}{|lccc|}
\hline & $\begin{array}{c}\mathrm{C}_{\mathrm{CO}_{2}} \\
\left(\mathrm{mmol} \mathrm{l}^{-1}\right)\end{array}$ & $\mathrm{pH}$ & $\begin{array}{c}\text { L-lactate } \\
\left(\mathrm{mmol} \mathrm{l}^{-1}\right)\end{array}$ \\
\hline Control & $2.1 \pm 0.2$ & $7.82 \pm 0.06$ & $0.54 \pm 0.12$ \\
Immersed & $1.8 \pm 0.6$ & $7.49 \pm 0.09$ & $9.82 \pm 1.34$ \\
Partially-emersed & $3.2 \pm 0.3$ & $7.91 \pm 0.11$ & $4.89 \pm 0.40$ \\
Emersed & $5.9 \pm 1.6$ & $7.16 \pm 0.05$ & $5.35 \pm 1.02$ \\
\hline
\end{tabular}

however, there was no significant decrease in the blood $\mathrm{pH}(p>0.01)$ despite the increases noted in both the $\mathrm{C}_{\mathrm{CO}_{2}}$ and lactate concentrations of the blood.

\section{DISCUSSION}

Palaemon elegans possesses a number of respiratory adaptations to withstand hypoxia but is unable to survive prolonged exposure to severe hypoxia or anoxia. Mortality rates among $P$. elegans maintained at oxygen tensions below 10 Torr for more than 3 to $4 \mathrm{~h}$ are high apparently due to an inability to maintain blood acidbase balance or to sustain anaerobic metabolism for long periods (Taylor \& Spicer 1987). This applies, however, only to prawns which, under laboratory condi- tions, do not have access to the air/water interface. The results of the present study demonstrate that by moving into shallow water at the edge of the pool $P$. elegans is able to exploit the higher oxygen tensions that may occur in these regions. (Interestingly, P. serratus, which is primarily a sublittoral species but may be found in low shore pools in which conditions rarely become very hypoxic [Taylor \& Spicer unpubl.] does not exhibit this behavioural response.) $P$. elegans also appears to utilize this behavioural strategy in the field. At night during periods of low tide when conditions within intertidal rock pools may become very hypoxic, $P$. elegans often moves into shallow regions of rock pools where the oxygen tension of the water may be significantly higher than in the deeper parts of the pools (Daniel \& Boyden 1975, Morris \& Taylor 1983). The occurrence of this behaviour was confirmed during the present study but it was also observed that when the pools became severely hypoxic or anoxic $P$. elegans exhibited the partial-emersion response that was observed in laboratory experiments.

Behavioural responses which enable animals to avoid severe hypoxia have been recorded in many aquatic species. For example, the freshwater prawn Macrobrachium rosenbergii is also known to migrate into the shallow regions of culture ponds when conditions become too hypoxic (Willis \& Berrigan 1977). There are also many examples of rock pool species which may leave the water completely when conditions become very hypoxic, e.g. the shore crab, Carcinus muenas (Taylor \& Bütier 1973, Daniei \& Boyden 1975), the amphipod Echinogammarus pirloti (Agnew 1985), the limpet Patella vulgata (Davies 1966), the gastropods Littorina spp. (Sandison in Lewis 1964) and the blenny Blennius pholis (Daniel 1971).

The partial-emersion response exhibited by Palaemon elegans in response to severe hypoxia has not been previously reported. It is known, however, that the freshwater prawn Macrobrachium australiense has a limited ability to migrate in air (Lee \& Fielder 1979 ) and $M$. rosenbergii has also been observed to propel itself out of hypoxic water in culture ponds (Smith et al. 1982). Similarly, the freshwater crayfish Austropotamobius pallipes migrates from hypoxic water into air where it can survive for up to $6 \mathrm{~d}$ if the relative humidity remains high (Taylor \& Wheatly 1980).

Complete emergence into air by Palaemon elegans was observed in the laboratory only during exposure to extreme hypoxia. This may be due to the prawns' apparent inability to obtain a supply of oxygen from air that is sufficient to maintain their normal rate of aerobic metabolism. When totally emersed, $P$. elegans has to rely, at least partly, on anaerobic metabolism. $P$. elegans is therefore faced with problems of acid-base 
disturbance due in part to the respiratory acidosis resulting from the cessation of branchial ventilation and the problems of $\mathrm{CO}_{2}$ elimination in air and to the metabolic acidosis associated with the production of lactic acid. These acid-base disturbances appear to be only partially compensated and result in a significant reduction in the $\mathrm{pH}$ of the blood.

The advantage gained by prawns emerging completely from hypoxic water appears, therefore, to be offset by the problems of acid-base disturbances of the blood. Furthermore, prawns emerging from hypoxic rock pools at night face the additional problem of returning to the pools (a task that is made difficult because they do not seem to be able to accurately control the direction in which they are propelled by the tail flicks) or being able to survive in air perhaps for several hours until the tide returns. It is perhaps not surprising, therefore, that during the present study, Palaemon elegans was not observed to emerge completely from rock pools at night when conditions became extremely hypoxic but instead moved into shallow water or exhibited the partial-emersion response.

The partial-emersion response during which prawns lie on their sides at the air/water interface at the edge of the pools enables them to exploit the higher oxygen tensions in this region of the pool without the problems of desiccation and of blood acid-base disturbance to which they would be exposed if they emerged completely into air. In this position, oxygen uptake probably takes place from the water and not directly from the air. By adopting this lateral position the scaphognathite in the branchial chamber that is uppermost is able to beat at the air/water interface and circulates water having a higher oxygen tension over the gills. Although it was not possible to carry out recordings of the rates of oxygen consumption of Palaemon elegans which were partially-emersed, it is likely that they were able to meet most of their metabolic demands via aerobic respiration. For although some L-lactate accumulated in these prawns, the blood concentrations were significantly lower than those of either completely emersed prawns or of prawns kept fully immersed under hypoxic conditions at the same temperature. The finding that the total oxygen content of the blood of partially-emersed prawns was significantly higher than in either fully immersed or emersed prawns provides further support to this suggestion.

The partial-emersion response shown by Palaemon elegans has some similarities with the emergence behaviour shown by the shore crab Carcinus maenas (Jobert 1896, Bohn 1897, Taylor \& Butler 1973, Taylor et al. 1973, 1977). In shallow hypoxic water, C. maenas raises the anterior part of the body and reverses the direction of scaphognathite beating so that air is bub- bled through the water remaining in the branchial chambers. This behaviour, as in $P$. elegans, ensures that the $P_{\mathrm{O}_{2}}$ of the water in the branchial chambers is increased and that oxygen uptake from the water can be maintained. The $P_{\mathrm{O}_{2}}$ at which $C$. maenas exhibits this emergence behaviour increases with increasing temperature (Taylor et al. 1973, 1977). A similar relationship was also observed in $P$. elegans and would be predicted in a situation in which the prawn is establishing an equilibrium between its ability to aerate the water in the branchial chambers and its absorption of oxygen by diffusion across the respiratory surfaces (Wheatly \& Taylor 1979).

By exhibiting this partial-emersion response both species are faced with fewer problems of blood acidbase balance than if they were to emerge completely into air. Thus in Carcinus maenas which were partiallyemersed, the acidosis in the blood was not as great as in crabs which had migrated out of the hypoxic water and remained totally emersed (Wheatly \& Taylor 1979) and indicates that the crabs are able to benefit from the presence of water in the branchial chambers to facilitate $\mathrm{CO}_{2}$ elimination (see also Burnett \& McMahon 1987). The ability to excrete $\mathrm{CO}_{2}$ into hypoxic water is also exploited by partially-emersed Palaemon elegans and by the crab Cancer productus when emersed under field conditions (DeFur \& McMahon 1983). In contrast to the acidosis recorded in the blood of C. productus emersed under laboratory conditions (DeFur \& McMahon 1984), the blood from crabs emersed in the field showed neither a significant acidosis nor an increase in $P_{\mathrm{CO}_{2}}$ (DeFur \& McMahon 1983). Similarly, in contrast to the acidosis recorded in the blood of fully emersed prawns, the blood $\mathrm{pH}$ of partially-emersed $P$. elegans increased significantly despite the slight increase in lactate production. This increase in blood pH may be attributable to a respiratory alkalosis resulting from the hyperventilation of the branchial chambers observed in these individuals.

Unfortunately, it was not possible to carry out comparative experiments on Palaemon elegans in the field. But the recent study of Truchot (1986) on Carcinus maenas has shown that the degree of acid-base disturbance experienced by both immersed and partiallyemersed crabs in the field may be less than that observed under laboratory conditions. It is possible, therefore, that by exhibiting the partial-emersion response when exposed to severe hypoxia in rock pools $P$. elegans is able to at least partially meet its respiratory requirements without suffering serious acid-base disturbances of the blood.

Acknowledgements. This work was supported by a NERC research grant (GR3/5311) to A.C.T. We thank Dr M. B. Jones for his assistance and hospitality during our visits to Plymouth. 


\section{LITERATURE CITED}

Agnew, D. J. (1985). The comparative ecophysiology of two species of intertidal amphipod. Ph. D. thesis, University of Glasgow

Bohn, G. (1897). Sur le renversement du courant respiratoire chez les Décapodes. C. I hebd. Séanc. Acad. Sci, Paris 125: 539-542

Booth, C. E., McMahon, B. R., DeFur, P. L., Wilkes, P. R. H. (1984). Acid-base disturbances during exercise and recovery in the blue crab, Callinectes sapidus. Respir. Physiol. 58: 359-376

Bridges, C. R., Bicudo, J. E. P. W., Lykkeboe, G. (1979). Oxygen content measurements in blood containing haemocyanin. Comp. Biochem. Physiol. 62A: 399-409

Burnett, L. E., McMahon, B. R. (1987). Gas exchange, hemolymph acid-base status, and the role of branchial water stores during air exposure in three littoral crab species. Physiol. Zool. 60: 27-36

Burton, R. F. (1987). On calculating concentrations of ' $\mathrm{HCO}_{3}$ ' from $\mathrm{pH}$ and $P_{\mathrm{CO}}$. Comp. Biochem. Physiol. 87 A: 417-422

Cameron, J. N. (1971). Rapid method for determination of total carbon dioxide in small blood samples. J. appl. Physiol. 34: $632-634$

Daniel, M. J. (1971). Aspects of the physiology of the intertidal teleost Blennius pholis (L.). Ph. D. thesis, University of London

Daniel, M. J., Boyden, C. R. (1975). Diurnal variations in physico-chemical conditions within intertidal rockpools. Field Stud. 4: 161-176

Davies, P. S. (1966). The physiological ecology of Patella I. The effect of body size and temperature on metabolic rate. J. mar. biol. Ass. U. K. 46: 647-658

Davenport, H. W. (1974). The ABC of acid-base chemistry. University of Chicago Press, Chicago

DeFur, P. L., McMahon, B. R. (1983). Analysis of hemolymph oxygen levels and acid-base status during emersion in silu' in ihe Red Ruck crab, Cancer productus. Biol. Buil. mar. biol. Lab. Woods Hole 165: 582-590

DeFur, P. L., McMahon, B. R. (1984). Physiological compensation to short-term air exposure in Red Rock crabs. Cancer productus Randall, from littoral and sublittoral habitats. II. Acid-base balance. Physiol. Zool. 57: 151-160

Graham, R. A., Mangum, C. P., Terwilliger, R. C., Terwilliger, $N$. (1983). The effect of organic acids on the oxygen binding of haemocyanin from the crab, Cancer magister. Comp. Biochem. Physiol. 74A: 45-50

Gutmann, I., Wahlefeld, A. W. (1974). L-t-lactate. Determination with lactate dehydrogenase and NAD. In: Bergmeyer, H. U. (ed.) Methods of enzymatic analysis, 2nd edn. Academic Press, New York, p. 1464-1468

Hagerman, L., Weber, R. E. (1981). Respiration rate, haemolymph oxygen tension and haemocyanin level in the shrimp Palaemon adspersus Rathke. J. exp. mar. Biol. Ecol. 54: 13-20

Jobert, M. (1896). Recherches sur l'appareil respiratoire et le mode de respiration de certaines Crustacés Brachyures (crabes terrestres). Ann. Sci. nat. Ser. Zool. Biol. anim. 4: 1-5

Lee, C. L., Fiedler, D. R. (1979). A mass migration of the freshwater prawn Macrobrachium australiense Holthuis (Decapoda: Palaemonidae). Crustaceana 37: 219-222

Lewis, J. R. (1964). The ecology of rocky shores. English Universities Press, London

McMahon, B. R., Burnett, L. E., DeFur, P. L. (1983). Carbon dioxide excretion and carbonic anhydrase function in the
Red Rock crab, Cancer productus. J. comp. Physiol. 154B: $371-383$

Morris. S., Taylor, A. C. (1983). Diurnal and seasonal variation in physico-chemical conditions within intertidal rock pools. Estuar coast. Shelf Sci. 17.339-335

Morris, S., Taylor, A. C. (1985). The respiratory response of the intertidal prawn Palaemon elegans (Rathke) to hypoxia and hyperoxia. Comp. Biochem. Physiol. 81A: 633-639

Morris, S., Taylor, A. C., Bridges, C. R., Grieshaber, M. K. (1985). Respiratory properties of the haemolymph of the intertidal prawn. Palaemon elegans (Rathke). J. exp. Zool. 233: $175-186$

Smith, T I. J., Sandifer, P. A., Jenkins, W. E. (1982). Growth and survival of prawns, Macrobrachium rosenbergii, pond reared at different salinities. In: New, M. (ed.) Giant prawn; republished. Elsevier Scientific Publishing Company, New York, p. 191-202

Stephenson, T. A., Zoond, A., Eyre, J. (1934). The liberation and utilization of oxygen by the population of rockpools. J. exp. Biol. 11: 162-172

Taylor, A. C. (1988). Ecophysiology of decapods in the rock pool environment. In: Fincham, A. A., Rainbow, P. S. (eds.) Aspects of the biology of decapod Crustacea. Symposium of the Zoological Society of London, Oxford University Press, No. 59: 227-261

Taylor, A. C., Spicer, J. I. (1987). Metabolic responses of the prawns Palaemon elegans and $P$. serratus (Crustacea: Decapoda) to acute hypoxia and anoxia. Mar. Biol. 95: $521-530$

Taylor, E. W., Butler, P. J. (1973). The behaviour and physiological responses of the shore crab Carcinus maenas during changes in environmental oxygen tension. Neth. J. Sea Res. 7: 496-505

Taylor, E. W., Butler, P. J., Al-Wassia, A. (1977). Some responses of the shore crab, Carcinus maenas (L.) to progressive hypoxia at different acclimation temperatures and salinsities. J. comp. Physiol. 119: 155-170

Taylor, E. W. Butler, P. J., Sherlock, P. J. (1973). The respiratory and cardiovascular changes associated with the emersion response of Carcinus maenas (L.) during environmental hypoxia at three different temperatures. J. comp. Physiol. 86: 95-115

Truchot, J. P. (1986). Change in the hemolymph acid-base state of the shore crab, Carcinus maenas, exposed to simulated tidepool conditions. Biol. Bull. mar. biol. Lab., Woods Hole 170: 506-518

Truchot, J. P., Duhamel-Jouve, A. (1980). Oxygen and carbon dioxide in the marine environment: diumal and tidal changes in rockpools. Respir. Physiol. 39: 241-254

Tucker, V. A. (1967). Method for oxygen content and oxygen dissociation curves on microliter blood samples. J. appl. Physiol. 23: 410-414

von Oertzen, J. A. (1982). A comparative study of the respiratory responses of Pomatoschistus micron (Krøyer) and Palaemon adspersus (Rathke) to declining oxygen tension. Ophelia 21: 65-73

Wheatly, M., Taylor, E. W. (1979). Oxygen level, acid-base status and heart rate during emersion of the shore crab Carcinus maenas (L.) into air. J. comp. Physiol. 132: 305-311

Willis, S. A., Berrigan, M. E. (1977). Growout of the giant Malaysia prawn. Macrobrachium rosenbergii in earthern ponds in central Florida. Complete Reports Florida Department of Natural Resources (2-206-Ra), 1-38 (Florida Department of Natural Resources, St. Petersburg, Fla.) 